\title{
Ampulla of Vater Large Cell Neuroendocrine Carcinoma
}

National Cancer Institute

\section{Source}

National Cancer Institute. Ampulla of Vater Large Cell Neuroendocrine Carcinoma. NCI

Thesaurus. Code C95985.

An aggressive, high-grade and poorly differentiated carcinoma with neuroendocrine

differentiation that arises from the ampulla of Vater and the periampullary region. It is characterized by the presence of malignant large cells. 